\title{
"The United States Cannot Afford to Lag Behind Russia": Making the Case for an American Nuclear Icebreaker, 1957-1961
}

\section{Peter Kikkert}

\begin{abstract}
Between 1957 and 1961, Representative Herbert Bonner and Senator Warren G. Magnuson spearheaded efforts to gain authorization for the US Coast Guard to construct and operate a nuclear-powered icebreaker. This article uses congressional hearings and debates and media coverage to conduct a frame analysis and map the arguments, themes, and stories - the language and discourse - used to convince decision-makers to build the vessel. While state competition became the central frame used by American nuclear icebreaker proponents, national security, science and technology, an uncertain future, and technical details about the existing fleet's decline were also popular narratives. Although the movement to secure authorization for the construction of a nuclear icebreaker enjoyed popular bipartisan and bi-cameral support in Congress, it failed to convince a budget-conscious Eisenhower administration, which insisted the Coast Guard required other vessels far more than icebreakers.
\end{abstract}

De 1957 à 1961, les membres du Congrès se sont efforcés d'obtenir l'autorisation de la Garde côtière américaine de construire un brise-glace à propulsion nucléaire. À l'aide d'audiences du Congrès, de débats et de reportages dans les médias, cet article effectue une analyse de cadre et recense les arguments, les thèmes et les récits qui ont servi à convaincre les décideurs de construire le navire. Alors que les partisans américains des brise-glaces nucléaires se sont principalement fiés à la concurrence entre états comme leur cadre principal, la sécurité nationale, la science et la technologie, un avenir incertain et des détails techniques concernant le déclin de la flotte existante étaient également des conceptions populaires. Bien que la pression en faveur d'un

The Northern Mariner / Le marin du nord 31, no. 1 (Spring 2021): 31-60 
brise-glace nucléaire ait bénéficié d'un appui populaire bipartite et bicaméral au Congrès, elle n'a pas réussi à convaincre l'administration Eisenhower soucieuse de son budget.

In 2018, the United States Department of Homeland Security sought $\$ 750$ million to procure a new heavy polar icebreaker and the lead materials required for a second. After initially receiving bipartisan, bi-cameral support, it appeared as though the Coast Guard's Polar Icebreaker Program - which aimed to construct three heavy and three medium icebreakers - would be able to launch into its construction phase. ${ }^{1}$ In late July, however, the House of Representatives Homeland Security Appropriations bill dropped the icebreaker funding and a later draft shifted the money to President Trump's border wall. ${ }^{2}$ In the midst of this budgetary struggle, the Coast Guard changed the longstanding name of the Polar Icebreaker Program to the Polar Security Cutter Program - a rebranding designed to generate greater support in the administration and Congress. Security, Coast Guard Commandant Admiral Karl Schultz argued, "that's what we're talking about: we're talking about national sovereign interests up there, we're talking about competition." The Polar Security Cutters represented the "face of that competition," Schultz insisted, particularly as Russia and China expanded their interests and capabilities in the region. ${ }^{3}$

In their assessment of the program rebrand, Lawson Brigham and Michael

1 Currently, the Coast Guard is pursuing its six-three-one approach to icebreaker acquisition. In January 2021, Admiral Schultz explained that "we need a minimum of six icebreakers. Within that six, three need to be heavy, or Polar Security Cutters as we [call] them. And we need one now." He has, however, indicated that the Coast Guard might attempt to acquire as many as six Polar Security Cutters, and three medium icebreakers (to be called Arctic Security Cutters) - for a fleet of nine US-flagged icebreakers. The operational classifications developed by the US Coast Guard and the Office of Science and Technology Policy (OSTP) define heavy icebreakers as "ships that have icebreaking capability of 6 feet of ice continuously at 3 knots, and can back and ram through at least 20 feet of ice." Medium icebreakers are defined as vessels capable of breaking through 4.5 feet ice continuously at 3 knots, with the ability to back and ram through ice at least 8 feet thick. Mallory Shelbourne, "Schultz: Nuclear Icebreakers Are Not An Option for Coast Guard," USNI News, 13 January 2021, https://news.usni.org/2021/01/13/schultz-nuclear-icebreakers-are-not-an-option-forcoast-guard; and Transportation Research Board and National Research Council, Polar Icebreaker Roles and US Future Needs: A Preliminary Assessment (Washington, DC: The National Academies Press, 2005), 16-23.

2 Rafael Bernal, "House funding bill scraps Arctic icebreaker program," The Hill, 13 December 2018, https://thehill.com/homenews/house/421314-house-funding-bill-scraps-arctic-icebreakerprogram; Melody Schrieber, "Funding for a long-awaited US heavy icebreaker is target of House GOP cuts," Arctic Today, 26 July 2018, https://www.arctictoday.com/funding-long-awaited-usheavy-icebreaker-target-house-gop-cuts/.

3 Ben Werner and Sam LaGrone, "Coast Guard Renames New Icebreaker Program 'Polar Security Cutter," USNI News, 27 September 2018, https://news.usni.org/2018/09/27/36846; Sabrina Shankman, "The US Military Needed New Icebreakers Years Ago. A Melting Arctic Is Raising the National Security Stakes," Inside Climate News, 3 December 2018, https://insideclimatenews. org/news/03122018/national-security-arctic-icebreaker-funding-emergency-climate-change-coastguard-military-readiness. 
Sfraga noted that it constituted "an effective strategy to communicate the important, multiple roles" played by icebreakers "within U.S. global maritime power" and argued that the move "might have been made decades ago." 4 The rebranding and arguments centred on state competition and national security proved persuasive. The final fiscal year 2019 budget included \$745 million for a polar security cutter. The Coast Guard and Naval Sea Systems Command awarded VT Halter Marine Inc. the contract to produce the country's first new heavy icebreaker in more than forty years, with an anticipated completion date of $2024 .^{5}$

In discussing the Polar Security Cutter program, Coast Guard Rear Admiral Melvin Bouboulis highlighted the central challenge with polar icebreaker acquisition in the US - talking about the need for "icebreaking capability...that doesn't sell very well to all audiences." Successive generations of American practitioners and policymakers have had to justify why the state requires an icebreaking capability - often to decision-makers with little to no knowledge of icebreakers. Why is it in the national interest for the US to possess polar icebreakers when they pose unique design and construction challenges, are difficult to operate and maintain, and come with a large price tag? ${ }^{7}$ The original US icebreaker fleet emerged with relative ease out of the national security exigencies of the Second World War. Since the 1950s, however, there has been a steady stream of official reports, departmental budgets, and congressional hearings justifying the need for additional and replacement polar icebreakers for the Coast Guard - "a long, tortuous history," according to Brigham, often marked by futility and failure. ${ }^{8}$

This long and tortuous history can be broken into four phases. The first phase was the failed congressional push for the construction of a Coast Guard nuclear icebreaker in the late 1950s. The second phase was the Coast Guard's request for four new heavy icebreakers in the late 1960s and early 1970s, which led to the construction of two: Polar Star and Polar Sea. The third phase covers the decade-long struggle spanning the 1980s and 1990s to construct two new heavy icebreakers, which culminated in the completion of the medium icebreaker, Healy. The ongoing fourth phase began in the early 2000s and is gaining momentum: full

\footnotetext{
4 Lawson Brigham and Michael Sfraga, "Why the US needs polar security cutters for the 21st century," Arctic Today, 27 December 2018, https://www.arctictoday.com/us-needs-polar-securitycutters-21st-century/.

5 Ronald O'Rourke, "Coast Guard Polar Security Cutter (Polar Icebreaker) Program: Background and Issues," Congressional Research Service, 11 March 2021, https://fas.org/sgp/crs/weapons/ RL34391.pdf.

6 Rear Admiral Melvin Bouboulis, the Coast Guard's Assistant Commandant for Engineering and Logistics, quoted in Werner and LaGrone, "Coast Guard Renames New Icebreaker Program 'Polar Security Cutter."”

7 As member of Congress Brian Baird succinctly put it: icebreakers "are not easy to make. They are not easy to operate. They are not easy to maintain. And they are not cheap." US Congress, House, Committee on Transportation and Infrastructure, Coast Guard Icebreaker: Hearings Before the Subcommittee on Coast Guard and Maritime Transportation of the Committee on Transportation and Infrastructure, 110th Cong., 1st sess., 2008.

8 Shankman, "The US Military Needed New Icebreakers Years Ago."
} 
funding has been secured for the first two Polar Security Cutters, while the fiscal year 2022 budget includes initial long lead time materials for a third. ${ }^{9}$

This article covers the first-phase efforts between 1957 and 1961 and is part one of a four-part study investigating the arguments used by various stakeholders to build their cases for Coast Guard polar icebreaker acquisition over the last 65 years. Specifically, this study uses official reports, congressional hearings and debates, and media coverage to conduct a frame analysis and map the arguments, themes, and stories - the language and the public discourse - that shaped how decision-makers understood the need for icebreakers and convinced or failed to convince them to build these vessels. ${ }^{10}$ Further, as the 1984 interagency Polar Icebreaker Requirements Study argued, "more than any other class of Coast Guard cutter, icebreakers are multi-mission vessels," 11 and this study also charts the different roles and missions that icebreaker advocates emphasized when making their cases - a key part of the broader discussion. Finally, it examines the objections and arguments used by those opposed to the construction of new icebreakers. In evaluating the public discourse around polar icebreaker acquisition, this study identifies successful frames that secured broad support for the construction of new American icebreakers. Conversely, it also helps to explain why these efforts so often ended in failure or partial success - and why the US icebreaking fleet currently consists of one, frequently broken down, 45-year-old heavy icebreaker and one ageing medium icebreaker.

Starting in 1957, Representative Herbert Bonner and Senator Warren G. Magnuson spearheaded the first-phase efforts to gain authorization for the US Coast Guard to construct and operate a nuclear-powered icebreaker and, when that failed, to build three conventional vessels while funding a study that would determine the practicality of providing them with nuclear propulsion. The congressional push came in response to the Soviet construction of the world's first nuclear icebreaker, Lenin. In the aftermath of Sputnik, and in the midst of national angst over a perceived missile gap, state competition became the central frame used by American nuclear icebreaker proponents - icebreaking could not become another area in which the US fell behind the Soviet Union. While competition dominated the discourse, national security, science and technology, an uncertain future, and the technical details about the existing fleet's decline were

\footnotetext{
9 O’Rourke, "Coast Guard Polar Security Cutter (Polar Icebreaker) Program;” Stew Magnuson, “Coast Guard Ship Modernization Under Full Steam,” National Defense, 3 March 2021, https:// www.nationaldefensemagazine.org/articles/2021/3/3/coast-guard-ship-modernization-under-fullsteam/.

10 The acquisition and budgetary processes in the US are incredibly complex. They involve a great deal of internal coordination and discussions between key agencies and the administration. In exploring the history of US icebreaker acquisition, this study purposely focuses on the arguments and materials used to frame public discussions, which were aimed at educating and convincing key Congressional stakeholders and, at times, the general public.

11 United States Coast Guard, United States Polar Icebreaker Requirements Study (Washington: US Department of Transport/US Coast Guard, 1984), 1-4.
} 
also popular narratives, with supporters emphasizing the wide array of security roles played by the icebreakers over their other duties. Although the movement to secure authorization for the construction of a nuclear icebreaker enjoyed popular bi-partisan and bi-cameral support in Congress, it failed to convince a budgetconscious Eisenhower administration, which insisted the Coast Guard required other vessels far more than icebreakers.

\section{Frame Analysis}

In policy studies, framing refers to how policy issues and information are communicated and categorized to organize meaning and create shared understandings. ${ }^{12}$ Frames represent a vital component of political discourse that work to prioritize certain understandings of an issue, give weight to select considerations over others, and establish the boundaries of discussion. ${ }^{13}$ Robert Entman's seminal study explains that the function of frames "is to select some aspects of a perceived reality and make them more salient in a communicating context, in such a way as to promote a particular problem definition, causal interpretation, moral evaluation, and/or treatment recommendation for the item described." 14 In doing so, frames serve as "interpretive storylines" that, whether presented as a "package of ideas" or a "central organizing idea," 15 set a "specific train of thought in motion, communicating why an issue might be a problem, who

12 For a recent overview of the literature on frames and framing, see Merlijn va Hulst and Dvora Yanow, "From Policy 'Frames' to 'Framing': Theorizing a More Dynamic, Political Approach," American Review of Public Administration 46, no. 1 (2014): 92-112, https://doi. org/10.1177/0275074014533142. Frame theory has been used by several Arctic experts to assess how the ideas and concepts used in media and state practice have shaped the political discourse on the region. M. Christensen, "Arctic Climate Change and the media: The news story that was," in Media and the Politics of Arctic Climate Change: When the Ice Breaks, eds. M. Christensen, A.E. Nilsson, and N. Wormbs (New York: Palgrave Macmillan, 2013), 26-51; Ekaterina Klimenko, Annika E. Nilsson, and Miyase Christensen, "Narratives in the Russian Media of Conflict and Cooperation in the Arctic," SIPRI insights on Peace and Security (August 2019): 1-32; Rebecca Pincus and Saleem Ali, "Have you been to 'The Arctic'? Frame theory and the role of media coverage in shaping Arctic discourse," Polar Geography 39, no. 2 (2016): 83-97, https://doi.org/10. 1080/1088937X.2016.1184722; E. Wilson Rowe, “A Dangerous Space? Unpacking State and Media Discourses on the Arctic," Polar Geography 36, no. 3 (2013): 232-244, https://doi.org/10.1080/1088 937X.2012.724461.

13 M.C. Nisbet, "Communicating Climate Change: Why frames matter for public engagement," Environment: Science and Policy for Sustainable Development 51, no. 2 (2009): 12-23, https://doi. org/10.3200/ENVT.51.2.12-23.

14 Robert Entman, "Framing: Toward Clarification of a Fractured Paradigm," Journal of Communication 43, no. 4 (December 1993): 51-58 at 52, https://doi.org/10.1111/j.1460-2466.1993. tb01304.x. See also Christian Burgers, Elly A. Konijn1 and Gerard J. Steen, "Figurative Framing: Shaping Public Discourse Through Metaphor, Hyperbole, and Irony," Communication Theory 26 (2016): 410-430, https://doi.org/10.1111/comt.12096.

15 Adam Koon, Benjamin Hawkins, and Susannah H. Mayhew, "Framing and the Healthy Policy Process: A Scoping Review," Health Policy Plan 31, no. 6 (2016): 801-816, https://doi.org/10.1093/ heapol/czv128. 
or what might be responsible for it, and what should be done about it." 16

Successful frames must effectively and clearly diagnose a problem, identify solutions and tactics, and motivate action. ${ }^{17}$ They are generally a "mixture of empirical information and emotive appeals." 18 Metaphors, catchphrases, stories, allusions to culture and literature, and historical comparisons are popular framing devices. ${ }^{19}$ An effective frame links concepts together in a manner that allows the audience to accept and understand the importance of the connection - for instance, linking icebreakers to broader concerns about state competition and national prestige. ${ }^{20}$ Baumgartner and Jones explain that to gain support in the US, frames should link ideas and issues to widely accepted values, including "progress, participation, patriotism, independence from foreign domination, fairness, economic growth." ${ }^{21}$ During their attempts to convince the Eisenhower administration to build a nuclear icebreaker in the late $1950 \mathrm{~s}$, key stakeholders would often link the vessel to several of these values, particularly patriotism and progress.

\section{A Short History of US Polar Icebreaking}

After the US purchased Alaska in 1867, the Revenue Cutter Service (predecessor to the Coast Guard) launched the Bering Sea Patrol and deployed ice-reinforced vessels to the area. While Corwin was a conventional steamer with a reinforced hull, Bear and Thetis were specifically constructed for work in icy waters and their strengthened frames allowed them to operate in the Bering Sea and along the Alaskan coast from the 1890s to the 1920s. Often the sole source of federal authority in the areas in which they operated, these vessels protected sealers and whalers, provided general law enforcement services, and responded to emergencies - though they were not icebreakers. With the retirement of Bear in 1927, these responsibilities fell to Northland, which was outfitted with a "cut away icebreaker bow and heavy plating to withstand ice pressures" but lacked the horsepower required for sustained icebreaking. ${ }^{22}$

16 Nisbet, "Communicating Climate Change."

17 Jörg Matthes, "Framing Politics: An Integrative Approach," American Behavioral Scientist 56, no. 3 (2012): 247-259 at 249, https://doi.org/10.1177/0002764211426324.

18 J.L. True, B.D. Jones, and F.R. Baumgartner, "Punctuated Equilibrium Theory," in Theories of the Policy Process 2nd Edition, ed. P. Sabatier (Cambridge MA: Westview Press, 2007), 161.

19 W.A. Gamson and A. Modigliani, "Media Discourse and Public Opinion on Nuclear Power: A Constructionist Approach," American Journal of Sociology 95, no. 1 (1989): 1-37 at note 19, https:// doi.org/10.1086/229213.

${ }_{20}$ Nisbet, "Communicating Climate Change," 17. See also D. A. Scheufele and D. Tewksbury, "Framing, Agenda-Setting, and Priming: The Evolution of Three Media Effects Models," Journal of Communication 57, no. 1 (2009): 9-20, https://doi.org/10.1111/j.0021-9916.2007.00326.x.

${ }_{21}$ F. Baumgartner and B. Jones, Agendas and Instability in American Politics (Chicago: University of Chicago Press, 1993), 7.

22 Donald L. Canney, "Icebreakers and the US Coast Guard," U.S Coast Guard Historian's Office, $\quad$ https://media.defense.gov/2019/Jul/25/2002162249/-1/-1/0/ICEBREAKERS D.\%20 CANNEY 1999.PDF; Polar Icebreaker Requirements Study, 1-3. 
Only in December 1936 did President Roosevelt's Executive Order No. 7521 give the Coast Guard responsibility for "keeping open navigation by means of icebreaking operations." In the years that followed, the service devoted considerable time and resources to the study of icebreaking in anticipation of constructing new vessels, including a survey of European states at the cutting edge of icebreaker design. ${ }^{23}$ Prior to the US entry into the Second World War, construction began on the light icebreaker Storis, which soon joined Northland and Bear on the Greenland Patrol - an operation that supported the re-supply of Greenland and patrolled its waters after the German occupation of Denmark. ${ }^{24}$

The construction of America's first modern "deep-draft" icebreakers began during the Second World War. Military exigencies provided a straightforward and compelling justification for the vessels: the US required vessels capable of breaking through heavy ice to resupply the Soviet Union and guarantee consistent access to military outposts constructed in Greenland. President Roosevelt directly intervened in the matter, stating simply, "I want the world's greatest icebreakers." 25 In November 1941, the US Coast Guard ordered four Wind-class icebreakers, designed by the prominent naval architecture firm Gibbs \& Cox and constructed by Western Pipe and Steel Company. The Coast Guard commissioned Northwind (eventually re-named Staten Island), Southwind, Eastwind, and Westwind between February and September 1944. As Dennis Bryant has pointed out, the Wind-class vessels were "the most technologically advanced icebreakers in the world." 26 They had bow propellers (so the vessels could back out of surrounding ice), diesel electric powerplants producing 12,000 horsepower, and a short length, which allowed them to follow leads in the ice. The hulls of the vessels were of "unprecedented strength and structural integrity" to resist 3000 pounds per square inch along the waterline..$^{27}$ In the fall of 1944, Eastwind and Southwind patrolled off Greenland, eliminated the last German weather station on the island, and captured the resupply freighter Externsteine. ${ }^{28}$ With their service in the supply and defence of Greenland no longer required, all the icebreakers except Eastwind were loaned to the Soviet Union as part of the Lend-Lease program.

Between 1945 and 1947, as its relationship with the Soviet Union deteriorated and the Arctic took on new strategic significance as a potential frontline in a future

\footnotetext{
23 Transportation Research Board and National Research Council, Polar Icebreakers in a Changing World: An Assessment of US Needs (Washington DC: The National Academies Press, 2007), 54.

24 Thaddeus Novak, edited by P.J. Capelotti, Life and Death on the Greenland Patrol, 1942 (Gainesville: University Press of Florida, 2005); and Canney, "Icebreakers and the US Coast Guard," 3-5.

25 Transportation Research Board and National Research Council, Polar Icebreakers in a Changing World, 54.

26 Dennis Bryant, "USCG Polar Security Cutters: The History and Future," MarineLink, 15 April 2020, https://www.marinelink.com/news/uscg-polar-security-cutters-history-477597.

27 Canney, "Icebreakers and the US Coast Guard," 6.

28 See, for example, Wilhelm Dege, translated and edited by William Barr, War north of 80: the last German Arctic weather station of World War II (Calgary, Alberta: University of Calgary Press, 2004).
} 
conflict, the US constructed three new Wind-class icebreakers. While the Coast Guard envisioned crewing each of these new vessels, dramatic service cutbacks left them with the "the alternative of taking all of them and manning part of them, putting the others in mothballs; or finally, an intermediate position." ${ }^{29}$ As a result, the Coast Guard took on the new Northwind, while Edisto and Burton Island joined the US Navy. In the summer of 1946, Northwind participated in Operation Nanook, which ventured to the waters off Greenland and the eastern Canadian Archipelago to study operating conditions in the Arctic and to offload construction engineers at Thule to erect an airstrip. Northwind, along with Burton Island, also provided icebreaking support for the eleven other vessels participating in Operation Highjump, a large-scale mission to the Antarctic that aimed to train personnel and test equipment in polar conditions, strengthen American territorial rights, and perform scientific studies. In the late 1940s, all three icebreakers supported the construction and resupply of defence installations across the North American Arctic, including the Joint Arctic Weather Stations on Canada's High Arctic Islands. ${ }^{30}$ In 1948, Northwind also resumed the Bering Sea Patrol and deployed annually along Alaska's north coast to provide, "native health care, icebreaking, law enforcement, marine safety, mail delivery, patrol, and other state and Federal co-operative missions." ${ }^{\prime 1}$

The Soviets returned their loaned icebreakers in the early 1950s, bringing the US polar icebreaking fleet to seven vessels, split between the Navy (Atka (the re-named Southwind), Staten Island (the original Northwind); Burton Island, and Edisto) and the Coast Guard (Eastwind, Westwind, and Northwind). The vessels re-entered service at a time of increased activity in both the Arctic and Antarctic. In the North, they supported a broad array of scientific initiatives and assisted in the construction of Thule air base and the Distant Early Warning (DEW) Line. Built along the 69th parallel to provide advanced warning of incoming Soviet bombers, the DEW Line, which became part of the binational US-Canada North American Air Defence Command (NORAD) established in 1958, consisted of seven sites in Alaska and twenty-two in Canada, stretched over 3000 miles from Lisburne on Alaska's northwest coast to Cape Dyer on the east coast of Canada's Baffin Island. Construction of the line "required the biggest task-force of ships assembled since the invasion of Europe" a Canadian official trumpeted in a 1957 magazine article, and the American icebreakers played pivotal roles in providing access to the construction sites and escorting transport vessels. ${ }^{32}$

\footnotetext{
29 US Congress, Senate, Atomic Icebreaker: Hearings Before the Committee on Interstate and Foreign Commerce, United States Senate, 85th Congress, 2nd sess. (28 May, 17 and 20 June 1958), 163 (statement of Vice Admiral A.C. Richmond, Commandant, United States Coast Guard).

30 See Peter Kikkert and P. Whitney Lackenbauer, "Setting an Arctic Course: Task Force 80 and Canadian Control in the Arctic, 1948," The Northern Mariner 21, no. 4 (2011): 327-358.

31 US Treasury Department, Report to the Secretary: Study of the Roles and Missions of the United States Coast Guard (Washington, DC: Department of the Treasury, 1962), I-13.

32 Quoted in P. Whitney Lackenbauer, "The Military as Nation-Builder: The Case of the Canadian North,” Journal of Military and Strategic Studies 15, no. 1 (2013): 1-34.
} 
Meanwhile, in the Antarctic, USS Atka performed an expeditionary cruise in 1954-1955 evaluating sites for the science stations the US planned to establish during the International Geophysical Year (1957-1958). As part of the country's growing interest in the polar regions, the US Navy constructed Glacier, which had superior ice-breaking capability, cargo capacity, science facilities, and endurance than the Wind-class vessels. ${ }^{33}$ In 1955-1956, Glacier, Edisto, and Eastwind escorted five other vessels to the Antarctic during Operation Deep Freeze I, which brought equipment, materials, and supplies for the upcoming IGY and constructed four

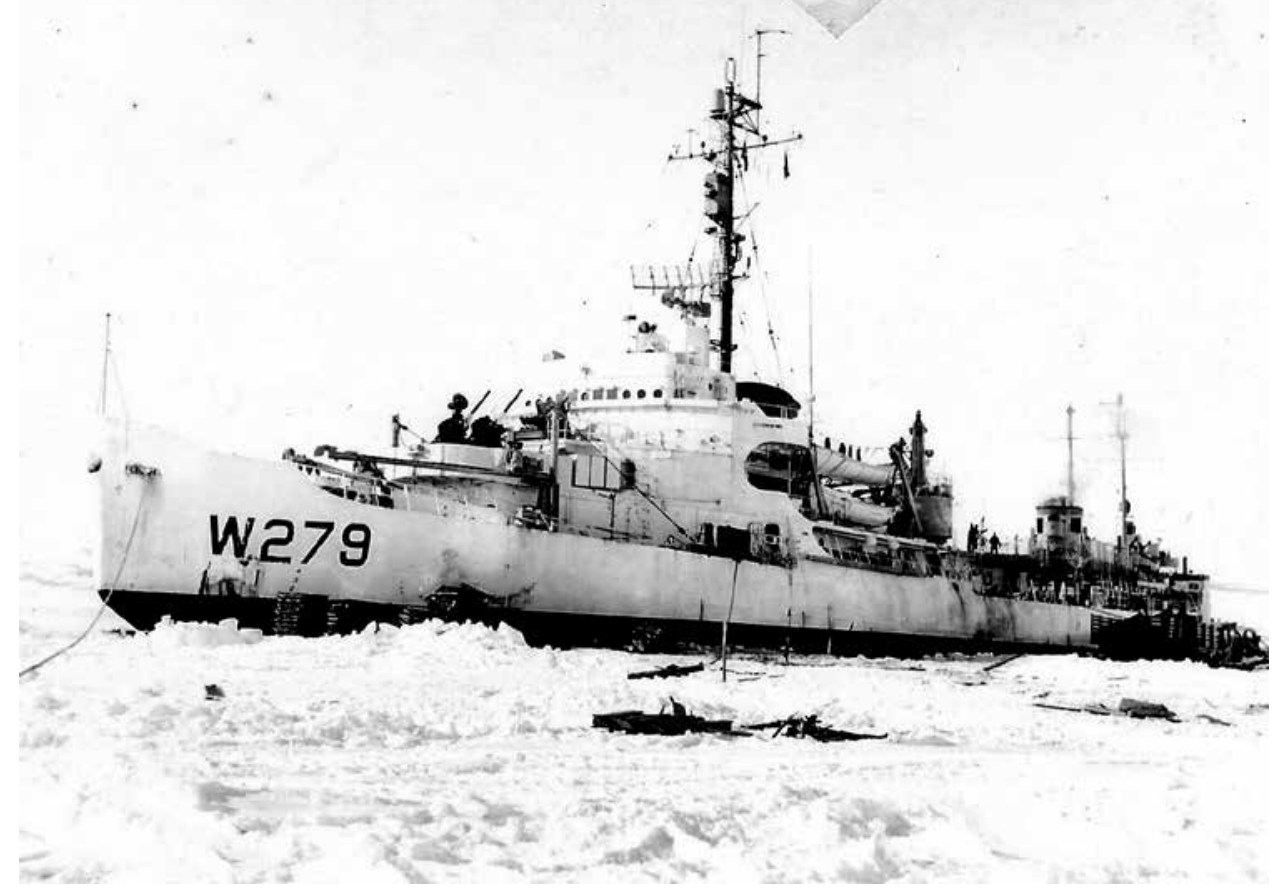

Image 1. The US Coast Guard icebreaker Eastwind in the ice, 1955. (US Antarctic Program Photo Library)

polar stations - including McMurdo and the Amundsen-Scott South Pole Station. Deep Freeze became an annual event for the icebreakers, which were tasked with breaking into McMurdo Sound and escorting the resupply vessels essential to maintenance of the American presence in the Antarctic, while conducting scientific operations as required. ${ }^{34}$

By the end of the 1950s, the US polar icebreaking fleet had proven essential to state activities in both the Arctic and Antarctic. Beyond the ice services they provided (icebreaking, ice reconnaissance), the ships continued to conduct

33 United States Polar Icebreaker Requirements Study, 1-3.

34 In 1968 they were also tasked with the resupply of Palmer Station on the Antarctic Peninsula. Canney, "Icebreakers and the US Coast Guard." 
the Coast Guard's other statutory missions: search and rescue and emergency assistance, marine safety, law and treaty enforcement, aids to navigation, environmental protection, and defence readiness. ${ }^{35}$ The icebreakers also adopted a variety of roles outside of their statutory missions, often in support of other government departments. Escort duty involved taking vessels (e.g. resupply, research, drilling) through ice-covered waters, creating an open water path for transits over a prolonged period, and maintaining an ice-free area around escorted ships. Logistic support duties involved use of the icebreakers as bases for other operations, generally providing personnel, fuel, food, shelter, communications, and transportation for field parties and detached boats and aircraft. The icebreakers also supported scientific activities, conducting observations, carrying research parties, and deploying and retrieving scientific equipment. Finally, icebreakers were used as sensor platforms to measure engineering parameters associated with icebreaking, to examine sea ice, and explore the possibilities of polar shipping. ${ }^{36}$ In short, by the 1950s, America's icebreakers were undertaking a wide array of missions in support of broad national objectives.

\section{A "first over the United States which it can advertise throughout the world": Responding to the World's First Nuclear-Powered Icebreaker}

In early 1956, news broke in the United States that the Soviet Union planned to build the world's first atomic icebreaker, Lenin. With a 44,000-horsepower engine and the endurance only nuclear power can provide, the 16,000-ton vessel raised the possibility of the atom finally unlocking the full potential of the Northeast Passage and transforming it "from a frozen asset into something equivalent to the Panama Canal for the United States." ${ }^{\text {37 }}$ I.K. Yakimovich, director of the Arctic Museum in Leningrad, explained that fuel had always been the primary problem limiting the endurance of the Soviet Union's icebreakers. "An icebreaker burning oil may consume as much as 70 tons of fuel in a day," he explained, "but an atomic vessel will use only about 45 grams of fuel in the same period of time - a quantity that easily would fit into a matchbox. ${ }^{\prime 38}$ As a result, if required, a nuclearpowered icebreaker could spend a full year operating in the ice, rather than two to three months. While construction of the vessel unfolded over the next two years, some American media reports praised the peaceful application of nuclear power represented by the icebreaker and characterized it as a scientific-technological

\footnotetext{
35 Lawson Brigham, "More Assets for the Arctic," United States Naval Proceedings 141, no. 2 (2015): 30-35.

36 Polar Icebreaker Requirements Study, 3/12-3/16.

37 Charles Klensch, "Icebreaker to Use A-Power," The Cincinnati Enquirer, 5 March 1956, 21; Howard Simons, "First Red Atomic Ship Will be Icebreaker," Lansing State Journal, 1 December 1956, 2; and Richard Stockwell, "Atomic Icebreaker to give Russia long-sought ship route to North," The Birmingham News, 2 September 1957, 34.

38 Richard Stockwell, "First A-Powered Surface Ship: It Gives Russia Route to North," Fort Worth Star Telegram, 18 September 1957, 6.
} 


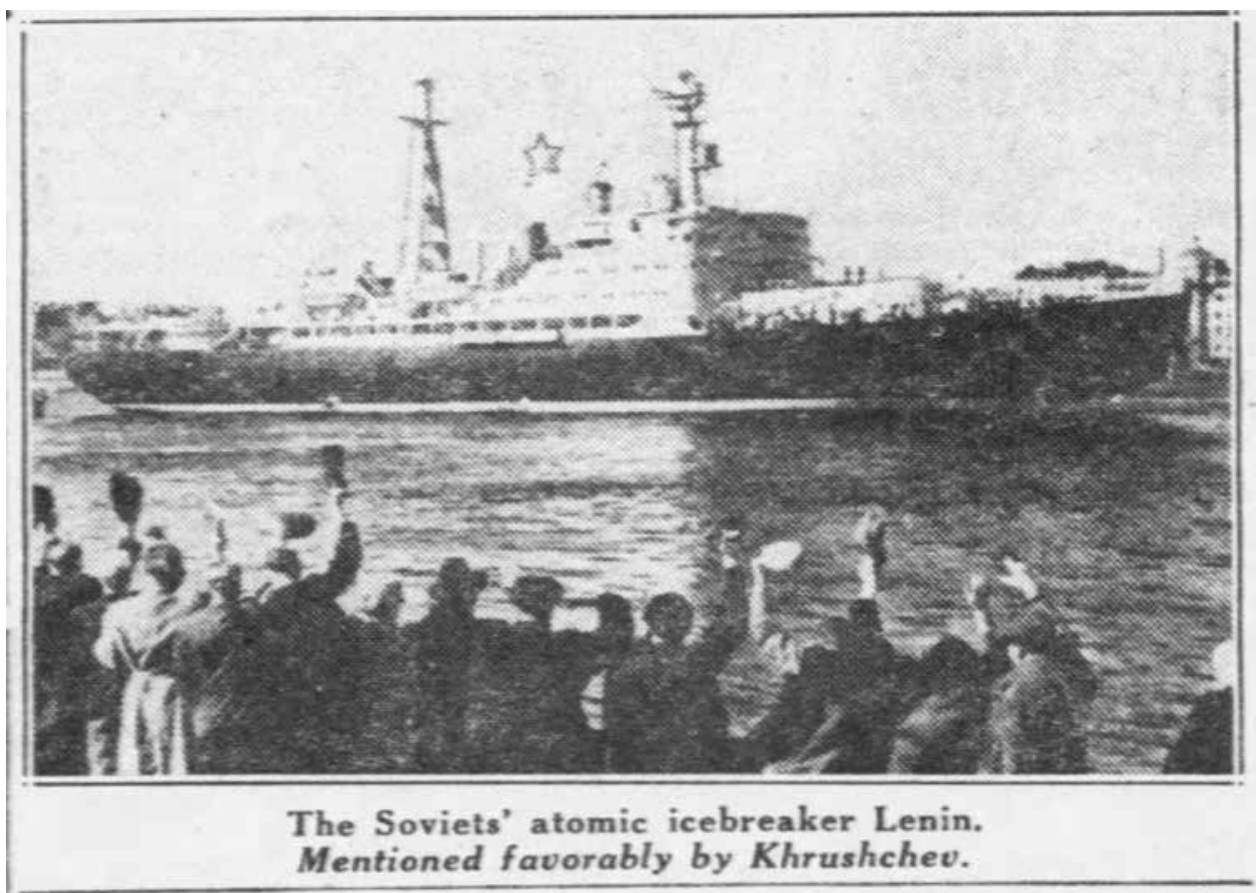

Image 2. The Soviet atomic icebreaker Lenin, 1959. (Daily News (New York), 16 September 1959, p. 87)

achievement that was "more practical" than the space programs of the US and Soviet Union. ${ }^{39}$

To many, however, Lenin's completion in December 1957 - just two months after the Soviet Union surprised the world by successfully launching Sputnik into low Earth orbit - was yet another example of the US falling behind its rival. Newspapers presented the icebreaker as an additional Soviet "first over the United States which it can advertise throughout the world." ${ }^{40}$ In 1956, Jane's Fighting Ships labelled the newly commissioned USS Glacier as the world's "largest highest powered icebreaker yet built," but, with its draft of 30 feet, length of 435.5 feet, beam of 90 feet, and its accommodations for 1000 crew members and passengers, Lenin easily seized the title. ${ }^{41}$ Lenin's launch also took some of the shine away from the polar accomplishments of the US Navy and Coast Guard that year. The Coast Guard tenders Storis, Spar, and Bramble had garnered international attention when they became the first US vessels to complete a transit of the Northwest Passage. ${ }^{42}$

39 Thomas Whitney, "Atomic Icebreaker More Practical than Sputnik," Tucson Daily Citizen, 27 October 1957, 31.

40 New York Herald Tribune News Service, "Plan Atomic Icebreaker," Valley Times, 9 November 1957, 17. Robert Allen, "A-Sub Race Tightens," The Pocono Record, 3 September 1957, 4.

41 "Russian Launch 1st Surface Atomic Ship," Spokane Chronicle, 6 December 1957, 2.

42 P.J. Capelotti, Across the Top of the World: The US Coast Guard's 1957 Northwest Passage Expedition (Washington: USGC Historian's Office, 2007). See, in this issue, Adam Lajeunesse and P. Whitney Lackenbauer, "Opening an Arctic Escape Route: The Bellot Strait Expedition," The 
Meanwhile, under the ice, the nuclear-powered submarine USS Nautilus had cruised northeast of Greenland to 87 degrees North, which included a 1383-mile under-ice transit in the central Arctic Basin. Despite these impressive feats, the construction of Lenin suggested that the Soviets were beating the US in icebreaker design and operation, the applied use of nuclear energy, and polar capabilities more generally.

These concerns resonated with Democratic Representative Herbert Bonner, the long-serving chair of the House Merchant Marine and Fisheries Committee, which was responsible for the annual Coast Guard budget authorization and covered an array of maritime affairs. Bonner had gained a reputation in the House as someone who "doesn't talk too much. So when he does talk, he challenges the attention of the House because he knows what he's talking about." ${ }^{43}$ As a representative of North Carolina's First District, which had a substantial Coast Guard presence, Bonner spent a great deal of time talking about the service and he proved one if its strongest supporters. US shipbuilding also interested him, and, by the mid-1950s, he had become a vocal proponent of the application of nuclear power to America's merchant fleet. When, in 1955, President Eisenhower proposed the construction of a nuclear-powered "peace ship" that would be an important part of his "Atoms for Peace" initiative, ${ }^{44}$ Bonner responded that the US should build a "practical" atomic-power merchant ship rather than the President's "International sideshow, carnival, or Mississippi River Showboat." 45 With Bonner as a leading advocate, this movement led to the construction and launch of the first nuclear-powered merchant ship, NS Savannah, in 1959.

Maritime affairs also interested Warren Magnuson, Democratic Senator from Washington State and Chairman of the Senate's Committee on Interstate and Foreign Commerce. He also supported Savannah's construction, arguing that the atomic merchant ship could serve as a prototype for future vessels that would further America's interests on the world's shipping routes. ${ }^{46}$ Throughout the 1950s, Bonner and Magnuson worked together on various maritime initiatives, ranging from the promotion of American shipbuilding to the ramping up of the country's ocean science and technology efforts. ${ }^{47}$ Early in 1957, for instance, the

Northern Mariner 31, no. 1 (2021): 1-29.

43 US Congress, Memorial Services held in the House of Representatives and Senate of the United States, 89th Congress, 1st sess., (1966) (remarks presented in eulogy of Herbert C. Bonner).

44 Richard Hewlett and Jack Holl, Atoms in Peace and War, 1953-1961 (Berkeley: University of California Press, 1989), 624-626.

45 “Another, Practical Atomic-Powered Merchant Ship Urged by Lawmakers," Herald and Review (Decatur), 17 May 1955, 1.

46 "Senate Passes Bill Authorizing Construction of \$37 million Atomic-Powered Merchant Ship," Tampa Morning Tribune, 21 June 1956, 37. NS Savannah was built at a cost of \$46.9 million (including a \$28.3 million nuclear reactor and fuel core) and launched on 21 July 1959.

47 William Merrell, Mary Hope Katsouros, Jacqueline Bienski, "The Stratton Commission: The Model for a Sea Change in National Marine Policy," Oceanography 14, no. 2 (2001): 11-16. In late 1957, the National Academy of Sciences established a Committee on Oceanography (NASCO) to study the state of marine science and research, technology, and education in the country. Members 
Table 1. General characteristics of Wind-class, Glacier-class, and proposed nuclear icebreakers.

\begin{tabular}{|c|c|c|c|c|}
\hline & Wind & Glacier & Nuclear Model 1 & Nuclear Model 2 \\
\hline Length & 269 feet & 310 feet & 350 feet & 453 feet \\
\hline Beam & 64 feet & 74 feet & 74 feet & 90 feet \\
\hline Draft (full load) & 29 feet & 29 feet & 26 feet, 6 inches & 30 feet \\
\hline Displacement & 6515 tons & 8450 tons & 9700 tons & 17,500 tons \\
\hline Horsepower & 10,000 & 21,000 & 30,000 & 45,000 \\
\hline Propulsion & $\begin{array}{l}\text { Diesel- } \\
\text { Electric }\end{array}$ & $\begin{array}{l}\text { Diesel- } \\
\text { Electric }\end{array}$ & $\begin{array}{l}\text { One nuclear } \\
\text { reactor }\end{array}$ & $\begin{array}{l}\text { Two nuclear } \\
\text { reactors }\end{array}$ \\
\hline No. of screws & 2 & 2 & 2 & 3 \\
\hline Maximum speed & $16 \mathrm{kts}$ & $17.5 \mathrm{kts}$ & $18 \mathrm{kts}$ & 20 knots \\
\hline Endurance & $\begin{array}{c}38,000 \\
\mathrm{~nm} \text { at } 10 \\
\mathrm{kts}\end{array}$ & $\begin{array}{c}25,000 \\
\mathrm{~nm} \text { at } 12 \\
\mathrm{kts} \\
\end{array}$ & $\begin{array}{l}6 \text { months of } \\
\text { stores }\end{array}$ & 1 year of stores \\
\hline Crew & 174 & 197 & 200 & 200 \\
\hline $\begin{array}{l}\text { Scientists and } \\
\text { other passengers }\end{array}$ & 8 & 16 & 40 & 100 \\
\hline $\begin{array}{l}\text { Icebreaker } \\
\text { Capability: } \\
\text { Continuous (at } 3 \\
\text { knots) }\end{array}$ & 3.2 feet & 4 feet & & \\
\hline $\begin{array}{l}\text { Tcebreaker } \\
\text { Capability: } \\
\text { Ramming }\end{array}$ & 11 feet & 14.5 feet & & \\
\hline Commissioned & $\begin{array}{l}1944- \\
1947\end{array}$ & 1955 & & \\
\hline Decommissioned & $\begin{array}{l}1968- \\
1989\end{array}$ & 1987 & & \\
\hline
\end{tabular}

two joined forces to criticize the Eisenhower administration's failure to adequately support domestic shipbuilding and the nation's merchant marine ship replacement program. ${ }^{48}$

The two politicians again teamed up to formulate a national response to Lenin's construction. The companion authorization bills (H.R. 9196, S. 3657) they proposed asked for "such sums as may be necessary, to remain available until expended, for the construction, outfitting, and preparation for operation, including training of qualified personnel, of a nuclear-powered icebreaking vessel capable of operation in icebound waters of the United States; and in the Arctic and Antarctic regions

of NASCO frequently briefed Bonner and Magnuson on its progress and the two politicians attended committee meetings. After NASCO released its 12-volume report, Oceanography 1960-1970, Magnuson introduced a resolution to strengthen oceanography in the US, while Bonner's Merchant Marine and Fisheries Committee established a subcommittee to study the report's recommendations. Magnuson later sat on the Stratton Commission, the recommendations of which inspired the creation of the National Oceanic and Atmospheric Administration (NOAA).

48 "Bill is Planned on Shipbuilding," Baltimore Sun, 9 August 1957, 11. 
as may be required." ${ }^{49}$ In the American congressional system, the authorizationappropriation process for federal spending to carry out government activities is "a primary avenue for exercising Congress's power of the purse." An authorization measure may create or continue an agency, program, or activity and authorize the subsequent enactment of appropriations. Legislative committees, such as the House Merchant Marine and Fisheries Committee, are responsible for authorizing legislation related to the agencies and programs under their jurisdictions. The next step in the process is to pass an appropriations act, which provides the funds for the authorized activity. ${ }^{50}$ Magnuson and Bonner's plan was to push through the authorization legislation to establish the need for a nuclear icebreaker in 1958, and then prepare an appropriation that could be passed in the next year's budget. Even if they could not immediately secure an appropriation for the icebreaker, the bill's supporters saw the utility in passing an authorization, for there was "merit of having this authority on the books" in case a future emergency demanded rapid action. ${ }^{51}$

The initial nuclear icebreaker envisioned by Bonner, Magnuson, and other supporters was 350 feet in length, with 30,000 horsepower, a maximum speed of 18 knots, a displacement of 9700 tons, and an estimated price tag of \$60 million. When the congressional committees discussing the bill fixated on the larger size and power of Lenin, however, Magnuson's Commerce Committee asked the Coast Guard to draw up two possible icebreaker models - one similar to the original version and another that would outmatch the Russian vessel. The larger model was 453 feet in length, with 45,000 horsepower, a maximum speed of 20 knots, a displacement of 17,500 tons, and an unspecified, but significantly higher cost. Both vessels would have considerable passenger accommodations for scientific expeditions, the space and fuel storage tanks for three helicopters, and significant cargo capacity to facilitate long stays in the ice. ${ }^{52}$

The legislative history of Bonner and Magnuson's atomic icebreaker bill is a winding one and the authorization request went through significant revisions.

\footnotetext{
${ }^{49}$ US Congress, House, A Bill to Authorize the Construction of a Nuclear-Powered Icebreaking Vessel for Operation by the United States Coast Guard, and for Other Purposes, H.R. 9196, 85th Cong., $1^{\text {st }}$ sess. (1958) and US Congress, Senate, A Bill to Authorize the Construction of a Nuclear-Powered Icebreaking Vessel for Operation by the United States Coast Guard, and for Other Purposes, S. 3657, 85th Cong., $1^{\text {st }}$ sess. (1958). H.R. 9196 was reported to the House on 5 June 1958 and passed on 26 June. It was reported to Senate on 24 July 1958 and passed on 21 July. President Eisenhower vetoed the bill on 12 August 1958.

50 Bill Heniff, "Overview of the Authorization-Appropriations Process," Congressional Research Service, 2012, https://crsreports.congress.gov/product/pdf/RS/RS20371.

${ }_{51}$ US Congress, House, Committee on Merchant Marine and Fisheries, Report No. 1057, Authorizing the Construction and Equipping of Three Coast Guard Cutters Designed for Icebreaking in the Arctic and Antarctic Regions, 86th Cong., 1st sess. (1959), 6.

52 US Congress, Senate, Committee on Interstate and Foreign Commerce, Report No. 1931, Authorizing the Atomic Icebreaker for Utilization by the United States Coast Guard, 85th Cong., 2nd sess. (1958), 12.
} 
After the bill's introduction in the summer of 1957, congressional hearings in the Senate's Committee on Interstate and Foreign Commerce and the House Merchant Marine and Fisheries Committee followed in the winter of 1958. The bill enjoyed strong bi-partisan support and, that July, the House and Senate debated, voted on, and approved the bill. On 12 August, however, President Eisenhower vetoed the measure..$^{53}$ Undeterred, Bonner and the senior Republican on the Merchant Marine and Fisheries Committee, Washington State Representative Thor Tollefson - a polar enthusiast who wanted the US to make a territorial claim in the Antarctic and thought a nuclear icebreaker would help - reintroduced two identical bills requesting authorization to construct such a vessel (H.R. 4 and H.R. 288) in early 1959. ${ }^{54}$ Based on feedback from congressional committee hearings that summer, however, Bonner and Tollefson combined their bills and modified their request to state: "That in the interest of national defense and to provide necessary facilities for the United States Coast Guard for the performance of its duties, the Secretary of the Treasury is hereby authorized and directed to construct and equip three cutters especially designed for icebreaking in the Arctic and Antarctic regions." Unwilling to give up their fight for a nuclear icebreaker, Bonner and Tollefson also included a provision for $\$ 500,000$ to study the feasibility of nuclear propulsion in an icebreaker to "assure that the cutters authorized ... shall be of the most advanced practicable design for the functions they will perform." ${ }^{55}$ While this bill passed through the House of Representatives in June 1960, no further action was taken during that congressional session. Finally, in early 1961, Senator Magnuson drafted a similar bill (S. 966), only to be given a resounding rejection from the Treasury Department. ${ }^{56}$

During the multi-year effort to secure authorization to construct new icebreakers for the US Coast Guard - first a nuclear vessel and then conventional ones - supporters consistently made their cases with the same frames. These frames, while persuasive enough to secure bi-partisan support in Congress, failed to convince the budget-conscious Eisenhower administration and key federal agencies.

\footnotetext{
53 Authorizing Construction of Nuclear-Powered Icebreaker - Veto Message from the President of the United States, Journal of the House of Representatives of the United States, 85th Cong., 2nd sess. (12 August 1958), 870.

${ }^{54}$ US Congress, House, A Bill to Authorize the Construction of a Nuclear-Powered Icebreaking Vessel for Operation by the United States Coast Guard, and for Other Purposes, H.R. 4 and H.R. 288, 86th Cong., $1^{\text {st }}$ sess. (1959); and "Rep. Tollefson Would Build an A-Icebreaker," The Capital Journal (Salem, Oregon), 16 December 1957, 7.

${ }_{55}$ US Congress, House, Committee on Merchant Marine and Fisheries, Report No. 1057, 6.

56 US Congress, Senate, Committee on Interstate and Foreign Commerce, Authorize the Construction and Design of Three Coast Guard Cutters Designed for Icebreaking: Hearings before the Merchant Marine and Fisheries Subcommittee of the Committee on Interstate and Foreign Commerce, 87th Cong., 1st sess. (9 and 10 March 1961), 154-155.
} 


\section{"We can do anything the Russians can do and do it better": State Competition Frame}

Throughout the bills, hearings, and debates on the construction of an American nuclear icebreaker, no frame proved more dominant than state competition. The story told by Bonner, Magnuson, and their allies, was a simple one: the Soviets had built a powerful nuclear icebreaker, the US was yet again falling behind its primary opponent, and action was required. This was a frame that members of Congress and the American public understood well. The launch of Sputnik shortly before Lenin's completion led to national anxiety in American society that the country was falling behind the Soviets in technological capabilities and losing the space race. In 1957 and 1958, the fictional idea that a missile gap - a perceived imbalance between the nuclear capabilities of the two countries - also took root in American society. ${ }^{57}$ Bonner frequently linked the need for an American nuclear icebreaker with these broader concerns. "Some time ago, America was amazed with the news of the first man-made satellite to be put in orbit, Russia's Sputnik," he noted in September 1959. With Lenin's launch shortly after, the Soviets also had "the greatest ship afloat for the study of oceanography ... It is unfortunate that the United States is far behind in this field and lacking in such comparable facility." 58 Much like Sputnik, the nuclear icebreaker served as a "lesson and a warning," Bonner argued, and to neglect the polar regions and cede leadership in these spaces to the Soviets would be "wasteful and dangerous." 59

William Francis Gibbs, the nation's leading naval architect whose firm had helped to design the Wind-class icebreakers, embraced this line of thinking during his testimony to the House Committee on Merchant Marine and Fisheries and in subsequent media comments. The US, he argued, had to prove it could exceed the Soviets in icebreaker design and construction. He unveiled a preliminary model for a nuclear icebreaker that was a staggering 589-feet long, with a beam of 105 feet, a displacement of 26,270 tons, and accommodations for 600 . It would be powered by three reactors and capable of 80,000 horsepower - far surpassing the power mustered by Lenin. "For God's sake let us get something that will be of use six or seven years from now," exclaimed Gibbs, "and show we can do anything the Russians can do and do it better." ${ }^{0}$

While simple arguments linked to state competition and national prestige appealed to members of Congress, the Coast Guard was quick to criticize the simplicity of this frame. Coast Guard Commandant Vice Admiral Alfred Richmond

\footnotetext{
57 See, for example, Christopher Preble, “'Who Ever Believed in the 'Missile Gap'?: John F. Kennedy and the Politics of National Security," Presidential Studies Quarterly 33, no. 4 (2003): 801826.

58 “Chances Dim for Building Icebreaker," Daily Press (Newport), 15 September 1959, 18.

59 US Congress, House, Committee on Merchant Marine and Fisheries, Atomic Icebreaker: Hearings before the Committee on Merchant Marine and Fisheries, 85th Cong., 2nd sess. (22-24 January 1958), 4.

60 John Finney, “Urges a Bigger Icebreaker,” The Kansas City Times, 14 August 1959, 22.
} 
thought that the congressional committee discussions relied too heavily on the "reasoning that since the Soviets are building an atomic icebreaker, we should build one also." Throughout the multi-year discussions on the issue, Richmond consistently noted that Russia had different icebreaking requirements than the US that necessitated more vessels and nuclear propulsion. He explained that,

Their needs are somewhat different than ours. Their coast is different, their icebreaking problems are different. Unlike our northern coast, the Canadian northern coast where you have a lot of islands and passes, theirs is practically an open coast with promontories. The ice collects on the promontories and they station their icebreakers on those points to act as escort vessels for 200 or 300 miles east of that point until the cargo vessel gets 200 or 300 miles west of that point at which time they get into the indentations and run in open water to the next promontory. I could see in their case, answering your question specifically on atomic power, they would have need to keep a vessel there for maybe several years and where fueling would be a considerable challenge. ${ }^{61}$

In short, the unique operational problems posed by the environmental conditions of the Northern Sea Route meant the Soviets would leave their icebreakers in the Arctic far longer than the US Coast Guard or Navy. Eventually, Richmond's point did gain traction in Congress. During the final committee discussions on the need for a nuclear icebreaker in 1961, Bob Bartlett, Democratic senator from Alaska, agreed that Richmond was "absolutely right...we can't compare mere numbers as between two big nations and say that we are necessarily lagging because we don't have as many icebreakers as the Russians, because their needs may not be the same at all, as you have told us." 62 The flawed idea that there was an icebreaker gap between Russia and the US that had to be closed, however, proved a resilient one and it featured prominently in all three subsequent phases of American polar icebreaker acquisition.

During the congressional hearings on the nuclear icebreaker bill, Richmond also testified that simple arguments about matching the Soviets "glossed over" the actual need for a nuclear icebreaker in the context of American polar requirements. Unless "we accept the premise that an atomic icebreaker is desirable, either for experimental or propaganda purposes," Richmond insisted, the need for such an icebreaker must first be established, which was the real challenge. ${ }^{63}$ Why, precisely, did the US require the capabilities delivered by a nuclear icebreaker? How could they further the country's core objectives in the polar regions and beyond?

\footnotetext{
61 US Congress, Senate, Committee on Interstate and Foreign Commerce, Atomic Icebreaker, 114115 (statement of Vice Admiral A.C. Richmond, Commandant, United States Coast Guard).

62 US Congress, Senate, Committee on Interstate and Foreign Commerce, Icebreakers, 163.

63 US Congress, House, Committee on Merchant Marine and Fisheries, Need for Coast Guard Icebreakers: Hearings before the Subcommittee on Merchant Marine of the Committee on Merchant Marine and Fisheries, 86th Cong., 1st sess. (13-14 August 1959), 45 (statement of Vice Admiral A.C. Richmond, Commandant, United States Coast Guard).
} 
To his credit, Magnuson tried to address Richmond's critique by linking America's need for nuclear icebreakers to two broader areas of state competition: what he called the "wet war" - dominance on and under the world's oceans - and the political control of the polar regions. "While America looks into space, we're losing a war with Russia right on our shores," he argued. Although Magnuson raised security concerns related to the size of the Soviet naval fleet, he also focused on their achievements in oceanography, marine science and technology, and their rapidly expanding merchant marine and fishing fleets. "Russia has been winning the wet war with more and bigger ships; more, if not better, scientists; more, and in some instances superior, equipment, and more aggressive government encouragement and action," he argued. "Her ships are modern, new; ours are old and obsolete." With the construction of Lenin, icebreaking represented yet another maritime field in which the US was falling behind. The Russians already operated twenty-nine polar icebreakers, compared to the eight possessed by the US, and they planned to build more. Magnuson's four-part plan to "recover our lost ground in the Wet War" included dramatically increasing the number of US submarines, expanding the merchant marine, funding more scientific research, and building a large fleet of "atomic powered crushers" that could open new commercial routes in the Arctic. ${ }^{64}$

The US also needed a fleet of "atomic powered crushers," Magnuson argued, in order to win the political competition for sovereignty in both the Arctic and Antarctic. Though he never clarified exactly what areas he was referring to islands, ice, ocean, or continental shelf - Magnuson stated that that Arctic was:

still a virgin international sovereignty field, practically, and with the Russians building an icebreaker right now, it seems to me we would have some real political considerations involved there ... If we do not get up there soon and stay there, with something like this icebreaker, and move around, I can just visualize, if the United Nations is still alive, the biggest debate going on about who owns the Arctic, between Russia and the United States. I believe it has great political significance; you can see that coming ... and if we do not move in the same time they do, or at a comparable time, we are going to have a problem. ${ }^{65}$

Without getting into the intricacies of international law, Magnuson insisted that a nuclear icebreaker's ability to maintain a nearly permanent presence in the Arctic and secure the country "squatters rights," to survey the ocean floor, and to keep potential sea lanes open, would allow the US to "establish sovereignty over that part of the arctic between the United States and Russia." 66 The state discussions that

\footnotetext{
${ }^{64}$ Warren Magnuson, "Why We're Losing 'Wet War': Russians Taking Over Seas Could Hold Fate of World," Pittsburgh Sun Telegraph, 31 May 1959, 53; and Warren Magnuson, "We're Losing Wet War," Pittsburgh Sun Telegraph, 1 June 1959, 6.

${ }^{65}$ US Congress, Senate, Committee on Interstate and Foreign Commerce, Atomic Icebreaker, 180 and 188 (statement of Senator Warren Magnuson).

66 “A-Icebreaker Bill Approved," The Wichita Eagle, 24 July 1958, 8.
} 


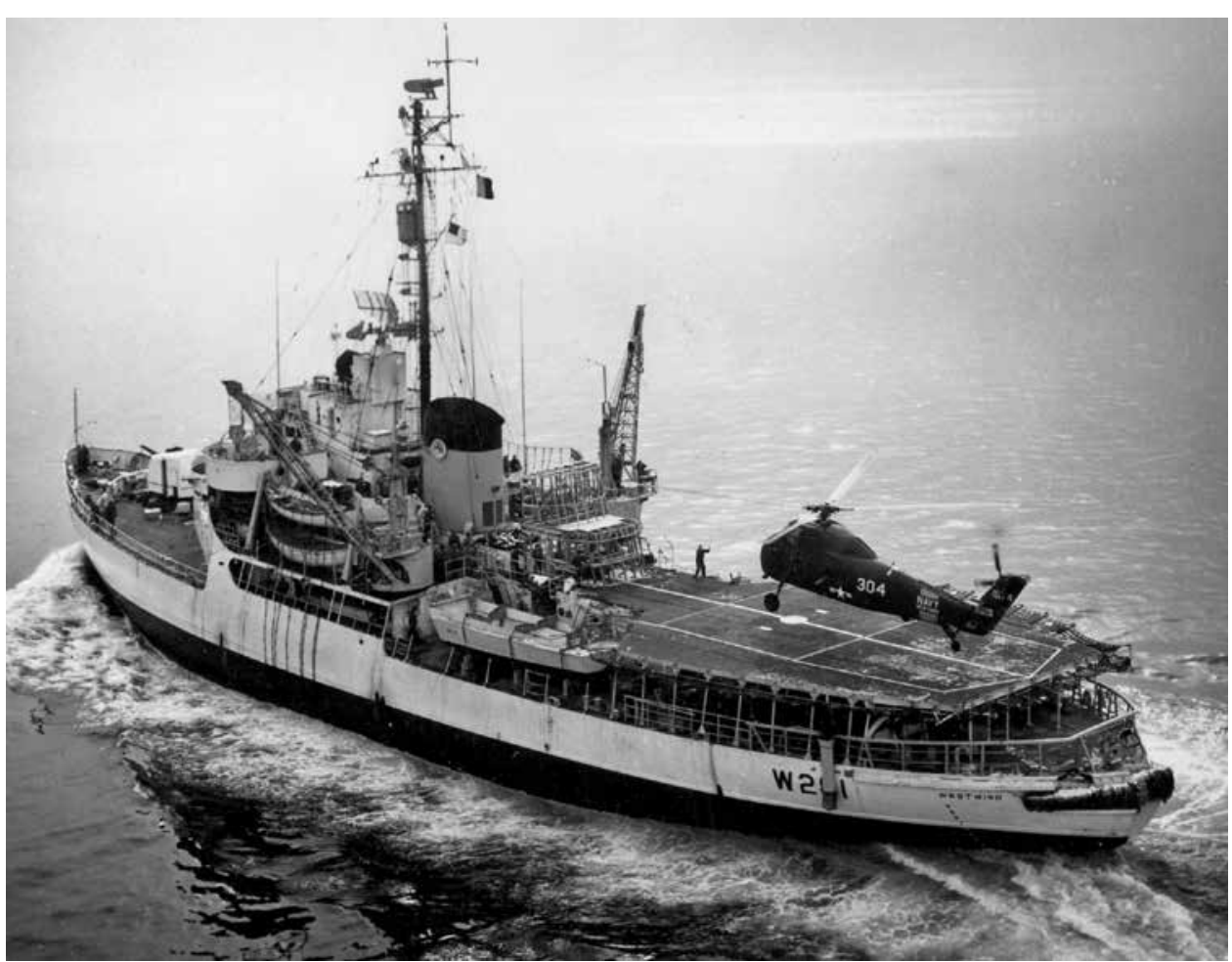

Image 3: A US Navy New York Naval Air Reserve Sikorsky HSS-1 Seabat landing on the deck of the US Coast Guard icebreaker Westwind operating off the east coast of the United States in 1961. (US Navy National Museum of Naval Aviation).

would eventually lead to the Antarctic Treaty (which essentially froze territorial claims) had already begun by the time Magnuson's nuclear icebreaker bill was up for debate, yet he maintained that "everybody is in there, everybody is going to try to establish sovereignty." ${ }^{67}$ With a nuclear icebreaker, the US could support American territorial rights across the continent - particularly to the unclaimed and inaccessible Marie Byrd Land with its ice-clad coastline. ${ }^{68}$

\section{"I cannot think of any more important vessel for the Arctic theatre": National Security Frame}

While closely related to broader considerations around state competition, national security was a distinct frame used by Bonner, Magnuson, and their allies to justify the need for a nuclear icebreaker. The American military footprint in the region had rapidly expanded during the early Cold War: weather, radar, and communications stations, air bases for Strategic Air Command and interceptors,

${ }^{67}$ US Congress, Senate, Committee on Interstate and Foreign Commerce, Atomic Icebreaker, 180 and 188 (statement of Senator Warren Magnuson).

68 US Congress, Senate, Committee on Interstate and Foreign Commerce, Atomic Icebreaker, 7074, 85 (statement of Dr. Paul Siple and Rear Admiral (retired) Charles Thomas). 
aerial surveillance, air defence systems, and early warning systems in Alaska, the Canadian Arctic, Iceland, and Greenland became pivotal parts of the American nuclear deterrent. ${ }^{69}$ The majority of these defence projects required extensive transportation services, which demanded the escort and logistical support of the American icebreaking fleet. During committee hearings on the nuclear icebreaker bill, multiple commentators highlighted that icebreakers had proven their military value in multiple construction and resupply missions, which were likely to continue in the foreseeable future. ${ }^{70}$

Essential as they are, retired Coast Guard Rear Admiral Charles Thomas seemed to understand that resupply operations do not have the same impact as arguments about combat requirements. Throughout much of the Second World War, Thomas had been involved in polar operations, first as commander of the cutter Northland on the Greenland patrol and then of Eastwind. Thomas had led the chase and capture of the German armed trawler Externstiene in the Greenland ice pack, and the incident had left him with strong feelings about the combat value of heavy icebreakers. "Well, let me put it this way," he argued in the congressional committee hearings on the proposed nuclear icebreaker. "There is a possibility that there may someday be a war, and there is a possibility that that war will certainly have an Arctic character; and I cannot think of any more important vessel for the Arctic theatre than an icebreaker." ${ }^{\prime 1}$ He warned that the Arctic constituted an exposed flank - a theatre of operations that the US was not prepared to defend. Thomas discussed the "war potential" of the icebreakers: as troop carriers, floating missile platforms, or even for naval action in ice-covered waters. ${ }^{72}$ While neither the Coast Guard nor US Navy repeated these points, Thomas' arguments featured prominently in the committee reports on the nuclear icebreaker bill. "We believe that construction of the proposed nuclear-powered icebreaker is in the national interest," noted the Commerce Committee's report to Senate, "to such a degree that failure now to grant the proposed authority would be almost tantamount to ceding to Russia full control of the Arctic regions in the event of future hostilities between the two leading world powers.' 73

Commentators also used national security concerns in the Antarctic to justify the need for American nuclear icebreakers. Well-known polar explorer Paul Siple, who had overwintered in the Antarctic four times and was frequently employed as

\footnotetext{
69 For an overview, see Peter Kikkert and P. Whitney Lackenbauer, "The Militarization of the Arctic to 1990," in The Palgrave Handbook of Arctic Policy and Politics, ed. Ken Coates and Carin Holroyd (Basingstoke: Palgrave Macmillan, 2020), 487-505.

${ }^{70}$ See US Congress, House, Committee on Merchant Marine and Fisheries, Report No. 1858, Atomic Icebreaker, 85th Cong., 2nd sess. (1958), 2-13; US Congress, House, Committee on Merchant Marine and Fisheries, Report No. 1057, 2-7; US Congress, Senate, Committee on Interstate and Foreign Commerce, Report No. 1931, 2-4.

${ }^{71}$ US Congress, House, Committee on Merchant Marine and Fisheries, Atomic Icebreaker, 85-86 (statement of Read Admiral (retired) Charles Thomas).

${ }^{72}$ US Congress, Senate, Committee on Interstate and Foreign Commerce, Atomic Icebreaker, 181.

${ }^{73}$ US Congress, Senate, Committee on Interstate and Foreign Commerce, Report No. 1931, 7.
} 
an expert by the US military, laid out a scenario in which enemy forces bombed or blocked the Panama Canal. In such a situation, the Drake Passage would serve as a vital sea lane connecting the Atlantic and Pacific, while Cape Good Horn, the Subantarctic Islands, and the Antarctic Peninsula would take on great strategic value. One of the nuclear icebreaker bill's primary supporters, Senator Tollefson, agreed, arguing that "[w]hoever controls the land down there could just play heck with us." 74 A nuclear icebreaker would provide the presence and security required to control this southern sea route in case of conflict.

Not all members of Congress were so easily convinced by arguments centred on the national security imperative of nuclear icebreakers. Michigan Republican Senator Clare Hoffman took issue with the explicit attempt to attach the icebreakers to national security. He insisted that that "committee has us over a barrel. There is no question about that. In the 'interest of national defense,' they stick that in. This gets votes in support of the bill. I vote for defense bills even though I know that two of every five dollars in it are wasted. We cannot do otherwise, when we do not know the necessity and danger to our national security. But this is a dilly." Other members of Congress agreed, pointing out that the US had submarines that could move under the ice and aircraft that could control the skies above it, which negated the possible combat roles icebreakers might take on in a future conflict. ${ }^{75}$

\section{A "crippling and perhaps crushing blow to both Arctic research and atomic research": Science and Technology Frame}

Science and technology proved a common frame, with supporters presenting the polar regions as chambers of secrets and nuclear icebreakers as the key to unlocking them. Retired Rear Admiral Leo Colbert, the director of the Arctic Institute of North America, argued that the kind of scientific research made possible by the icebreaker would finally lead to the "peaceful conquest of the far north." "76 Dr. John Reed, renowned polar expert and geologist with the US Geological Survey, noted that "the Arctic is not the closed area that it used to be and the requirement for modern knowledge of the Arctic under this concept is increasing and urgent." 77 Paul Siple explained that, to this point, American research and exploration in the Antarctic depended on aircraft, tractors, and dog teams - an icebreaker would open up significant opportunities to expand this research into as yet untouched areas. ${ }^{78}$ Studies in the polar regions, the scientists argued, would benefit the world by providing insight into global weather patterns, atmospheric

\footnotetext{
74 US Congress, House, Committee on Merchant Marine and Fisheries, Atomic Icebreaker, 7172; and "Tollefson Urges US to Pursue Antarctic Territorial Claims," Spokane Chronicle (Spokane, Washington), 28 December 1957, 8.

75 Authorizing Construction of Three Coast Guard Cutter, H.R. 4, 6 June 1960, 86th Cong., 2nd sess., Congressional Record 106, pt. 9: 11934-11939.

76 US Congress, House, Committee on Merchant Marine and Fisheries, Report No. 1858, 8.

77 US Congress, House, Committee on Merchant Marine and Fisheries, Atomic Icebreaker, 29.

78 US Congress, House, Committee on Merchant Marine and Fisheries, Report No. 1858, 9-10.
} 
conditions, oceanography, and a host of other key areas. They also underlined that both the Arctic and Antarctic might hold great mineral and fisheries potential, but further scientific study was required to find out. ${ }^{79}$ A nuclear icebreaker would provide the access required to answer these questions.

This frame was closely connected to arguments about national security and state competition. Magnuson argued that the US simply could not "afford to lag behind Russia in the exploration and research required to understand, and to benefit by the knowledge of, these largely unknown areas." ${ }^{\circ 0}$ The Pentagon viewed knowledge of the Arctic environment as vital for waging a war against the Soviets. US defence research focused on geophysical fields such as meteorology, geology, seismology and oceanography, and the Pentagon initiated and funded projects across Alaska, the Canadian Arctic, and Greenland.$^{81}$ During the icebreaker hearings, the US Navy explained that a nuclear icebreaker would be useful in obtaining vital scientific information related to meteorology, bathymetry, sea ice and currents, drift and water structure, sonar propagation, and sea ice prediction - all of which would assist US submarines operating under the ice. ${ }^{82}$

The construction of a nuclear icebreaker, its supporters maintained, would also allow the US to demonstrate its leadership in nuclear technology. Kenneth Fields, with the Atomic Energy Commission, noted that construction of such a vessel was technically feasible, would provide important experience developing reactor technology, and offered an ideal opportunity to show America's commitment to the peaceful and practical application of atomic power. ${ }^{83}$ Magnuson agreed. Reflecting on the scientific benefits that could be accrued by a nuclear icebreaker, he concluded that failure to build the vessel would serve a "crippling and perhaps crushing blow to both Arctic research and atomic research." 84

\section{"The Wind class vessels cannot last": The Technical Frame}

Supporters of the push for a nuclear icebreaker and of the bill for conventional replacement icebreakers also framed it as a technical issue: the Wind-class icebreakers were old, outdated, and should be replaced by the most modern and powerful vessel possible. The report to the House of Representatives filed by Bonner's Committee on Merchant Marine and Fisheries highlighted that seven

\footnotetext{
79 US Congress, Senate, Committee on Interstate and Foreign Commerce, Report No. 1931; and US Congress, House, Committee on Merchant Marine and Fisheries, Report No. 1858.

80 US Congress, Senate, Committee on Interstate and Foreign Commerce, Atomic Icebreaker, 159 (statement of Chairman Warren Magnuson).

${ }^{81}$ See, for instance, Matthais Heymann, Henrik Knudsen, Maiken L. Lolck, Henry Nielsen, Kristian H. Nielsen, and Christopher J. Ries, "Exploring Greenland: Science and Technology in Cold War Settings," Scientia Canadensis 33, no. 2 (2010): 11-42.

${ }^{82}$ US Congress, House, Committee on Merchant Marine and Fisheries, Atomic Icebreaker, 44.

83 Letter from K.E. Fields, General Manager, Atomic Energy Commission to Hon. Herbert Bonner, 15 January 1958, in US Congress, House, Committee on Merchant Marine and Fisheries, Atomic Icebreaker, 3.

84 "President Explains A-Icebreaker Veto," The Marlow Review, 28 August 1959, 2.
} 
of the eight polar icebreakers possessed by the US had been designed prior to the Second World War and grew more obsolete every year. To support this observation, Bonner referenced an after-action report written by Rear Admiral George Dufek, commander of Operation Deep Freeze from 1955 to 1959, which stated, "The only icebreaker to join the U.S. fleet since the war is the Glacier and even she is showing signs of her years of hard usage. The Wind class vessels cannot last through many more seasons of operation in the summers of both hemispheres with minimum maintenance time between. Timely construction of at least one new icebreaker is imperative." Dufek went on to comment that, "as for the powerplant, a nuclear powered ship would be most desirable from the point of fuel conservation." 85

Icebreaking expert Rear Admiral Charles Thomas supported these statements, arguing that one Lenin would be better than ten of the current Wind-class icebreakers. ${ }^{86}$ He revealed that his greatest concern when conducting operations in the ice was running out of fuel and getting locked in the ice. "That is why my hair is gray - one of the reasons," he told Congress. "Comparing fuel requirements in icebreakers, an ice-mile may be equal to a thousand sea-miles because of the toughness of the pack. The need for conservation of fuel materially reduced the mobility of our icebreakers." $"{ }_{77}$ Glacier, Thomas pointed out, could only remain in the Antarctic for three months, the Wind-class icebreakers for two. A nuclear icebreaker would have practically unlimited cruising range and endurance, and, if designed properly, could be used to carry cargo to supply inaccessible land or ice bases, without the need to escort transport vessels. ${ }^{88}$ In short, a nuclear icebreaker would solve many technical problems - and save future captains from going prematurely gray.

Several commentators - including serving members of the Coast Guard and Navy - admitted that the icebreaker fleet's current operations were pushing the vessels and crews to their absolute limits. The fleet only met these demands through near continuous operation. ${ }^{89}$ During the congressional hearings in 1958 , however, the US Navy made it clear a nuclear icebreaker was simply not a priority. At this point, the Navy's nuclear priorities centered on providing nuclear reactor power for naval submarines, followed by aircraft carriers, with surface warships a distant third.

Notably absent from the congressional testimony and public discussion on the nuclear icebreaker was Vice Admiral Hyman Rickover, known as the "father of the nuclear navy." His position on the Atomic Energy Commission's Division

\footnotetext{
85 US Congress, House, Committee on Merchant Marine and Fisheries, Report No. 1057, 4.

86 “On the Inside," Fairbanks Daily News Miner, 10 February 1958, 4.

87 US Congress, Senate, Committee on Interstate and Foreign Commerce, Atomic Icebreaker, 180 (statement of Read Admiral (retired) Charles Thomas).

${ }^{88}$ US Congress, House, Committee on Merchant Marine and Fisheries, Report No. 1858, 11.

${ }^{89}$ US Congress, House, Committee on Merchant Marine and Fisheries, Need for Coast Guard Icebreakers, 6-8 (statement of Vice Admiral Ray Gano, USN, Commander, Military Sea Transportation Service).
} 
of Reactor Development and, in particular, his leadership role as Director of the Naval Reactors Branch, allowed him a great deal of control over the application of nuclear propulsion to US ships. ${ }^{90}$ Although Rickover had spoken out in favour of an atomic merchant ship in 1956, he remained silent on the need for an American nuclear icebreaker. In December 1957, however, he remarked on Lenin's launch, noting that it was "easier to develop the atomic power plant for a surface ship than a submarine" and it was "more important to have the nuclear submarine first." Unlike surface vessels, nuclear-powered submarines could go anywhere in the Arctic Ocean, exploring, charting, and conducting scientific studies with ease. ${ }^{91}$ In July 1959, the Soviets gave Rickover a much-publicized personal tour of Lenin. Journeying to Leningrad as part of Vice President Nixon's party, the admiral explored the ship for an hour and, after much protest, was permitted to view the vessel's reactor. Rickover reported that "it looks like a first-class job, but since I don't have X-ray eyes, I can't look inside those reactors.... It does not represent an advance in the reactor art... It is a fine job, a good job for the purpose for which it was planned." 92 While the tour provided Rickover an ideal opportunity to comment on whether the US required a similar icebreaker, he instead highlighted the need for more nuclear submarines.

Despite various Coast Guard representatives underlining the extensive and exhausting mission set undertaken by the service's icebreakers during the 1958 congressional hearings, Vice Admiral Richmond concluded that, "based on specific known and immediate requirements of the Service... I cannot document or justify an additional icebreaker." 93 During the next year's icebreaker hearings, however, the commandant changed his tune. Over the previous few years, resupply operations in the Arctic had shown "that age is beginning to take its toll" on the icebreakers. In 1955, Eastwind suffered a major hull fracture "you could practically drive a truck through" after relatively minor contact with the ice. During ice operations in 19581959, Richmond reported, both Eastwind and Westwind reported considerable hull damage in the same area, which raised concerns about the structural integrity of the entire fleet. ${ }^{44}$ Richmond argued that the fact the icebreaking fleet continued to accomplish its missions should not be read by the administration as proof that all

\footnotetext{
90 See, for instance, Richard G. Hewlett and Francis Duncan, Nuclear Navy: 1946-1962 (Chicago: The University of Chicago Press, 1974) and Francis Duncan, Rickover and the Nuclear Navy: The Discipline of Technology (Annapolis: US Naval Institute Press, 1990).

91 “Rickover Sees Nautilus First Under Polar Ice," Tampa Bay Times, 6 December 1957.

92 John Scali, “Tour After Protest," The Troy Record, 28 July 1959. At Leningrad's shipyard Nixon gave a speech highlighting that as the Soviet Union built its icebreaker, the US was building an atomic merchant ship, showcasing the desire of both nations to use atomic power for peace. "We must work together to break the ice," Nixon concluded.

93 US Congress, House, Committee on Merchant Marine and Fisheries, Atomic Icebreaker, 105-106 and 117 (statement of Vice Admiral Alfred Richmond).

94 US Congress, Senate, Committee on Interstate and Foreign Commerce, Authorize the Construction and Design of Three Coast Guard Cutters Designed for Icebreaking, 155-159; and US Congress, House, Committee on Merchant Marine and Fisheries, Need for Coast Guard Icebreakers, 46-48.
} 
was well - "in icebreaker support the United States is operating on a margin that is either insufficient or too close for safety." The evidence was mounting that "time is running out for the icebreakers" and that the US should launch a prompt and immediate icebreaker building program..$^{95}$

\section{"We have to project our imaginations": Preparing for an Uncertain Future}

Supporters of an American nuclear icebreaker frequently framed the vessel as one solution to the Arctic's uncertain future. Rear Admiral Thomas set the tone when he argued that, "in planning for the requirements of an icebreaker, I do not think we should focus our attention upon what the needs are today. I think that would be a very shortsighted policy. I think we have to project our imaginations into what are going to be the requirements we will need 10 or 15 years from now." ${ }^{66}$ In the near future, he argued, the Coast Guard might be required to deliver more of its traditional services in the Arctic, particularly law enforcement, search and rescue, and icebreaking in support of commerce. Thomas noted that air routes would continue to push northward along the great circle routes, and that an icebreaker would be required to "get within at least helicopter range of any plane disaster," while commercial shipping routes could also be established in the region. ${ }^{97}$ Thomas' admonishment that the Eisenhower administration must use its "brains and imagination" when considering the need for nuclear icebreakers, won him praise from the press, particularly after the Coast Guard failed to support the nuclear icebreaker bill in 1958. Thomas, reported the Fairbanks Daily Miner, was "one rebel who won't go along with the brass." Instead, he was "fighting the same kind of battle as Billy Mitchell did for the airplane, and Hyman Rickover for the atomic-powered submarine." 98

Other commentators joined Thomas in painting a picture of a future in which icebreakers would be vital to the national interests of the US in the Arctic. Dr. David Nutt, research associate in geography at Dartmouth College, noted that "every year brings forth new and expanded requirements" and these would only intensify in the future. ${ }^{99}$ Whether it be to help secure American sovereignty, defend its polar interests, or advance science, Magnuson stated that the authorization for a nuclear icebreaker "could be one of the most important bills which Congress could pass with respect to the effect on our future." 100 In highlighting the uncertain

\footnotetext{
95 US Congress, House, Committee on Merchant Marine and Fisheries, Need for Coast Guard Icebreakers, 47-48.

96 US Congress, House, Committee on Merchant Marine and Fisheries, Atomic Icebreaker, 84 (statement of Rear Admiral (retired) Charles Thomas).

${ }^{97}$ US Congress, House, Committee on Merchant Marine and Fisheries, Report No. 1858, 10-13; US

Congress, Senate, Committee on Interstate and Foreign Commerce, Atomic Icebreaker, 182.

98 "On the Inside," Fairbanks Daily News Miner, 10 February 1958, 4.

99 US Congress, House, Committee on Merchant Marine and Fisheries, Atomic Icebreaker, 167.

100 Senator Magnuson speaking on S. 3657, 85th Cong., 2nd sess., Congressional Record (31 July 1958), 15705.
} 
future of the polar regions, Bonner also tried to bring all of the frames together into one coherent narrative. He saw a future in which state competition increased dramatically in the polar regions because "we have not scratched the surface of the potentialities of the Arctic and Antarctic." "101 A nuclear icebreaker would help the US to complete the science necessary to understand the region, while offering it the technology and capabilities required to meet a range of potential security missions. To drum up support, he connected the uncertain future in the polar regions to historical events that would resonate with his audience in Congress and the general public. "I think it is well at this point," he argued, "to call to mind the cost in money and lives resulting in World War II from our failure to heed the warning and advice of those who with foresight and knowledge urged such projects as the fortification of Guam and the charting of the Aleutians." These failures to act had threatened the US war effort. ${ }^{102}$ Lest history repeat itself, Bonner explained, America had to invest in a nuclear icebreaker, and do so immediately.

\section{"Not Urgently Needed at this Time": The Administration's Response}

Bonner and Magnuson's initial authorization request for the construction of a nuclear icebreaker hit its first roadblock during committee hearings in early 1958. The Bureau of the Budget - which produced the president's budget and examined agency programs, policies, and procedures to see whether they fit with the president's priorities - advised the Treasury Department, of which the Coast Guard was a part, that "it does not favor the enactment of the bill and considers it unwise to place the construction of a nuclear-powered icebreaker ahead of ships regarded by the Coast Guard and the Navy as more essential." ${ }^{103}$ Despite the Coast Guard and the US Navy acknowledging both the age and heavy employment of their Windclass icebreakers, both services told the congressional committee hearings that icebreaker replacement was not a priority. ${ }^{104}$ The Treasury Department and Coast Guard officially reported that the service had more pressing programming needs, including smaller vessels and new cutters. ${ }^{105}$ The Department of Commerce argued

\footnotetext{
101 US Congress, House, Committee on Merchant Marine and Fisheries, Atomic Icebreaker, 4 (statement of Representative Herbert Bonner).

102 Representative Bonner speaking on the Presidential Veto of H.R. 9196, 85th Cong., 2nd sess., Congressional Record (22 August 1958), 19215.

103 Letter from A. Gilmore Flues, Acting Secretary of the Treasury to Senator Warren Magnuson, 17 June 1958, US Congress, Senate, Committee on Interstate and Foreign Commerce, Report No. $1931,7-8$.

${ }^{104}$ See, for instance, Letter from Arleigh Burke, Office of the Chief of Naval Operations, to Herbert C. Bonner, 10 March 1958, in US Congress, House, Committee on Merchant Marine and Fisheries, Report No. 1858, 21-22; E.C. Stephan, Rear Admiral United States Navy, Chief of Legislative Liaison, to Representative Herbert Bonner, 15 January 1958, in US Congress, House, Committee on Merchant Marine and Fisheries, Atomic Icebreaker, 2; and US Congress, House, Committee on Merchant Marine and Fisheries, Atomic Icebreaker, 150 (statement of Rear Admiral A.G. Mumma, Chief of Navy's Bureau of Ships, Department of the Navy).

105 A. Gilmore Flues, Acting Secretary of the Treasury to Herbert Bonner, 15 January 1958 in US
} 
that the nuclear icebreaker bill "should be postponed. Extensive expenditures by the Federal Government during the past several months have resulted in serious budgetary problems. In view of this, every effort should be made to hold down expenditures for projects which are not urgently needed at this time."106

Despite the negative reports from these key federal agencies, the first nuclear icebreaker bill enjoyed strong bi-partisan support and easily made it out of committee. While some members of Congress pushed back on the bill, arguing that with the high level of US debt the icebreaker could not be considered a necessary expenditure, the bill easily passed through the House and Senate. ${ }^{107}$ President Eisenhower did not, however, find the estimated \$60-million price tag of the proposed vessel warranted. "This bill," noted Eisenhower, "in providing for a project which is not needed, fails to take account of the present fiscal situation of the Government. A continued disregard of our budgetary problems through the institution of unneeded new programs and projects can only add to inflationary pressures to the detriment of all the people." The president's veto of the authorization also concluded that "placing the construction of an icebreaker arbitrarily ahead of high-priority projects in the Coast Guard program would be most unwise." 108

The administration doubled down on these arguments during the subsequent efforts by Bonner, Magnuson, and Tollefson to pass an authorization for a nuclear icebreaker. In the spring of 1959, the Treasury Department rejected the new bill, explaining that it was not in accord with the administration's program and priorities. ${ }^{109}$ The US Navy also reported that the passage of time had only further nullified the need for a nuclear icebreaker. The benefits the icebreaker could have brought as a scientific data-collection platform had been replaced by the recent submarine operations of the nuclear-powered Nautilus and Skate. ${ }^{110}$ Only the Coast Guard's view had changed. Growing increasingly concerned about the longevity of the Wind-class icebreakers, Richmond convinced Bonner to change the bill to authorize the construction of three conventional icebreakers and $\$ 500,000$ to study if the vessels should be powered by nuclear propulsion. The Coast Guard's support,

Congress, House, Committee on Merchant Marine and Fisheries, Atomic Icebreaker, 2-3.

106 Sinclair Weeks, Secretary of Commerce, to Warren Magnuson, 20 June 1958 in US Congress, Senate, Committee on Interstate and Foreign Commerce, Report No. 1931, 10-11.

107 US Congress, House, Committee on Merchant Marine and Fisheries, Report No. 1057.

108 Authorizing Construction of Nuclear-Powered Icebreaker - Veto Message from the President of the United States, Journal of the House of Representatives of the United States, 85th Cong., 2nd sess. (12 August 1958), 870.

109 A. Gilmore Flues, Acting Secretary of the Treasury, to Representative Herbert C. Bonnet, 2 April 1959, in US Congress, House, Committee on Merchant Marine and Fisheries, Report No. 1057, 8-9. 110 R.L. Kibbe, Captain, USN, Deputy Chief of Legislative Liaison, to Representative Hebert C. Bonner, 31 March 1959 in in US Congress, House, Committee on Merchant Marine and Fisheries, Report No. 1057, 9-10; and US Congress, House, Committee on Merchant Marine and Fisheries, Need for Coast Guard Icebreakers, 24 (statement of Rear Admiral Glynn R. Donaho, Rear Admiral, USN, Director, Logistics Plans Divisions). 
however, was not enough. The Department of Commerce's response to the revised bill noted that "desirability alone is not a sound criterion for adding to Federal responsibilities." "111 The last hearings before Magnuson's Interstate and Foreign Commerce committee also soundly rejected the need to conduct a feasibility study on providing America's icebreakers with nuclear propulsion. ${ }^{112}$ The final dismissal of the bill came from the Treasury Department in March 1961, which noted that its position remained the same: the Coast Guard required replacement vessels of other categories far more than new icebreakers. ${ }^{113}$

\section{Conclusion: "Our Traditional Lethargic Attitude"}

Between 1957 and 1959, Bonner, Magnuson, Tollefson, and their supporters worked to gain authorization for the construction of a nuclear icebreaker. When that failed, they switched tactics to gain support for the construction of three conventional icebreakers, which could be converted to nuclear-powered vessels after the completion of a feasibility study. The frames they employed - state competition, national security, science and technology, the need to prepare for an uncertain future, and the technical details of a declining icebreaking fleet gained bi-partisan political support in the House of Representatives and the Senate. They could not, however, attain the backing of key federal departments or the administration.

Reflecting upon this failure, Representative George Miller (Democrat) explained it as part of a systemic issue in Washington. He noted that the vessels of the modern American icebreaking fleet were all "war babies" born in a moment of extreme and unprecedented crisis. Echoing similar arguments made about the missile gap, Miller pondered if the hesitancy around securing additional icebreakers was rooted in "our traditional lethargic attitude toward these things that we wait until we get into a war before we start building the tools that we need with which to fight a war." Soon the situation in the polar regions would require powerful icebreakers and the US would be behind. ${ }^{114}$ Notwithstanding his doubts, Miller suggested to his fellow icebreaker proponents that consistent messaging and regular attempts might be able to win the support required to overcome their country's lethargy. "I think we have come to the place where it is just a matter of salesmanship," he concluded. "If we keep knocking at the door and asking them to

\footnotetext{
111 Frederick H. Mueller, Acting Secretary of Commerce, to Representative Herbert C. Bonner, 3 April 1959, US Congress, House, Committee on Merchant Marine and Fisheries, Report No. 1057, 11-12.

${ }^{112}$ US Congress, Senate, Committee on Interstate and Foreign Commerce, Authorize the Construction and Design of Three Coast Guard Cutters Designed for Icebreaking.

${ }^{113}$ US Treasury Department, Report to the Secretary: Roles and Missions of the United States Coast Guard, June 1962, I-4 and I-5.

${ }^{114}$ US Congress, House, Committee on Merchant Marine and Fisheries, Need for Coast Guard Icebreakers, 9 (statement of Representative George Miller).
} 
buy, sooner or later, maybe to get rid of us, they are going to buy the program." ${ }^{115}$

Bonner, however, was not so sure. The administration's response to the icebreaker bills highlighted its regular tendency to ignore the Coast Guard. "This important agency has been suffering continuing neglect in recent years and is failing to keep abreast of current developments due in large part to inadequate or obsolescent equipment handed down from the other services," Bonner pointed out. ${ }^{116}$ With insufficient funding and a broad set of vital missions requiring an array of cutters, aircraft, and shoreside assets, it would always be a struggle to prioritize icebreaker acquisition. Bonner was correct - limited funding and arguments that the Coast Guard required other assets more would continue to waylay icebreaker acquisition efforts in the years ahead. ${ }^{117}$

While Coast Guard Commandant Vice Admiral Richmond shared Bonner's concerns, he also forwarded the idea that supporters of a nuclear icebreaker, or even conventional icebreakers, had to do a better job of presenting them as a national interest - of selling the "specific need" for the vessels and situating them in the "bigger picture." In the late 1950s, he argued, the Wind-class icebreakers were conducting far more operations for other government departments than traditional Coast Guard missions and the lack of "immediate requirement for pure Coast Guard usage" may have unduly shaped the administration's negative response. ${ }^{118}$ Though proponents of the icebreaker bill had connected the vessels to concrete needs, such as national security and scientific research, Richmond maintained that more had to be done to explain why the country required icebreakers. Supporters, Richmond elaborated, had to elevate the discussion and tie icebreakers to the nation's broader policy objectives in the polar regions and beyond. ${ }^{119}$ As Commandant Admiral Karl Schultz argued when making the case for new icebreakers in 2018, "that's what we're talking about: we're talking about national sovereign interests." 120

Even as the efforts of Bonner, Magnuson, and other politicians failed to secure authorization for new icebreakers, the Coast Guard's interest in procuring replacement vessels grew as its vessels approached "physical obsolescence." By 1962, the Secretary of the Treasury agreed with the service and acknowledged there was a need for new icebreakers - in part because of predictions that Alaska's new statehood might increase commercial activities in the region. ${ }^{121}$ In 1964, the

\footnotetext{
115 US Congress, House, Committee on Merchant Marine and Fisheries, Need for Coast Guard Icebreakers, 44 (statement of Representative George Miller).

116 Representative Bonner speaking on the Presidential Veto of H.R. 9196, 85th Cong., 2nd sess., Congressional Record (22 August 1958), 19215-16.

117 Brigham, "More Assets for the Arctic," 30-35.

118 US Congress, Senate, Committee on Interstate and Foreign Commerce, Atomic Icebreaker, 166 (statement of Vice Admiral Alfred Richmond as shared by Rear Admiral James Hirschfield).

119 US Congress, House, Committee on Merchant Marine and Fisheries, Atomic Icebreaker, 105-106 and US Congress, Senate, Committee on Interstate and Foreign Commerce, Atomic Icebreaker, 175. ${ }^{120}$ Werner and LaGrone, "Coast Guard Renames New Icebreaker Program 'Polar Security Cutter."

${ }^{121}$ US Treasury Department, Report to the Secretary: Study of the Roles and Missions of the United States Coast Guard, I-13.
} 
Coast Guard received a small fund to begin designing a replacement icebreaker. A year later, the Department of Defense, the Treasury Department, and the Bureau of the Budget determined that a single agency should operate all eight US icebreakers to ensure efficiency of operations, leading to the transfer agreement that sent the Navy's icebreakers to the Coast Guard. This also meant that primary responsibility for procuring new icebreakers fell on the shoulders of the Coast Guard. The service had learned lessons from the administration's response to the nuclear icebreaker bills. It found that "old justifications fell short of the mark" and "the many "whys' asked by the probing administrators" demanded a "fresh approach to our aging problem." Icebreakers had to be framed as part of the broader national interest and related to specific policy priorities. This was the primary objective of the extensive Polar Transportation Requirements Study. ${ }^{122}$ Its purpose was to establish the link between what would be spent on an icebreaker and how it would be used, connecting resources to purpose, and justifying the acquisition of new vessels. For now, however, the best efforts of Bonner, Magnuson, and their allies had failed, and the US would have to wait another fifteen years for a new icebreaker.

Peter Kikkert is the Irving Shipbuilding Chair in Arctic Policy and Assistant Professor of Public Policy and Governance in the Brian Mulroney Institute of Government at St. Francis Xavier University, Nova Scotia, Canada.(Contact: pkikkert@stfx.ca)

${ }^{122}$ US Coast Guard, Polar Transportation Requirements Study Report: Vol. I (Washington, D.C.: US Department of Transportation/US Coast Guard, 1968), 4-5. 